Mr. Belkisa Dolić ${ }^{1}$, Mr. Nedim Haračić

\title{
ARAPSKE MODALNE PARTIKULE I ADEKVATNOST NJIHOVIH PRIJEVODNIH EKVIVALENATA U BOSANSKOME JEZIKU: SURA ET-TEKASUR
}

\section{Sažetak}

Uvodni dio rada pruža kratak uvid u problematiku koja se vezuje uz prevodilački zanat i uz modalne riječi kao kategoriju čija borba za lingvistički identitet traje već dugo, a konačan ishod se tek odskoro počeo nazirati na obzorju pragma(lingvis)tičkih $i$ diskursnih studija. Osnovni cilj rada je utvrdivanje $i$ opisivanje komunikativno-pragmatickih funkcija arapskih modalnih partikula hatta, kella, sevfe, sume, lev, le i n (lit-te'kid) te njihove aktualizacije u suri Et-Tekasur, a potom procjenjivanje adekvatnosti postojecih prijevodnih ekvivalenata za iste u bosanskome jeziku kao $i$ iznalaženje novih, kompetentnijih u slučaju da se takav postupak nametne kao potreban. Kao korpus poslužit će nam sura Et-Tekasur u izvornome Kur'anu (na arapskome jeziku) te u sedam njegovih prijevoda na bosanski jezik: Ali Riza Karabeg (1991), Džemaluddin Čaušević i Hammed Pandža (1969), Besim Korkut (1977), Mustafa Mlivo (2004), Enes Karić (1995), Esad Duraković (2004) i Muhamed Mehanović (2013).

Ključne riječi: modalne riječilizrazi, riječce, diskursne oznake, polifunkcionalnost, ekvivalenti

\section{Uvod}

Prevoditeljstvo se često naziva Sizifovim poslom na osnovu čega se da naslutiti koliko ono umije biti mukotrpno, isprazno i uzaludno. Umije, ali ne mora biti ako prevoditelj dobro razumije original i ima istančan osjećaj za ciljni jezik te ako pored toga dvojezičnog raspolaže potrebnim vanjezičnim znanjima. Evo zašto prevodilac mora biti tako dobro „opremljen“: autor jezički tretira (tj. kodira) određenu stvarnost pomoću

${ }^{1}$ Pedagoški fakultet Univerziteta u Bihaću. 
jezičkih sredstava svoga jezika selektirajući ih i kombinirajući po vlastitome izboru dok prevodilac taj produkt prvo dekodira, a potom ga nanovo kodira u sistemu svoga jezika s posebnom opreznošću da se od njega nimalo smisaono ne udalji i kao takvog ga prosljeđuje na ponovno dekodiranje širem krugu recipijenata/čitaoca koji nisu u stanju informaciju crpiti iz prve ruke (up. Levi 1982). Kratko rečeno, autor ima samo autorsku ulogu, čitaoci isključivo recipijentsku dok prevodilac najprije mora odigrati ulogu recipijenta, a nakon toga i ulogu autor-posrednika (medijator između različitih jezika, ali i različitih kulturnih krugova²).

Diskursne oznake, tačnije modalne riječi i izrazi kao njihova potkategorija, spadaju u red prevoditeljima najomraženijih riječi i izraza. Njihova „semantička nedefiniranost i netransparentnost" (Brinton 1996: 34) ili bolje reći njihovo „suptilno izdiferencirano značenje“, kontekstualna uslovljenost i iz nje proizašla polifunkcionalnost predstavljaju ogromni problem prevodiocima jer zbog svega navedenog većina modalnih riječi/izraza nema jedan adekvatan ekvivalent u drugom jeziku. Adekvatan ekvivalent u ciljnom jeziku bi bio onaj koji posjeduje sve značenjske finese i funkcionalne sposobnosti kao i modalna riječ/izraz u polaznome jeziku, a takvo podudaranje je gotovo nemoguće. Zato će najčešće biti ili doslovno, odnosno „suho“, prevedeni ili prešutno proglašeni nesavladivim poteškoćama, tzv. ostacima u procesu prevođenja, i kao takvi potpuno zanemareni, tj. prevedeni „nultim ekvivalentom “3 (up. Nigoević 2011b: 136). No, prevodioci svjesni njihovog značaja će se ipak upustiti u zahtjevan poduhvat: najprije će se potruditi da proniknu u autorovu intenciju kako bi iskristalizirali značenje i funkciju modalne riječi/izraza u određenom kontekstu, a potom joj moraju pokušati naći što približniji ako već nije moguće iznaći totalni - funkcionalni ekvivalent pa makar on

\footnotetext{
2 (up. Džanko, 2010).

${ }^{3}$ No takav postupak ne treba uvijek izjednačavati sa prevoditeljevom nemarnošću i ljenošću jer ako prevodi sa jezika koji obiluje modalnim partikulama (kakav je, naprimjer, njemački) na jezik čiji je fond istih oskudan - a oskudan je jer njihova egzistencija u tom jeziku nije nužna (ne postoje bogati/siromašni jezici) - bolje da ih u određenim slučajevima izostavi kako prijevod ne bi djelovao pretrpano, neprirodno i nategnuto.
} 
u ciljnome jeziku nemao isti leksički oblik (npr. umjesto jedne riječi u jeziku originala, upotrebljava se parafraza u ciljnome) ili čak ni status modalne riječi/izraza (njima katkad može biti funkcionalni ekvivalent modalni perfekt, potencijal, relacioni dativ, naglašeni oblik ličnih zamjenica, rečenična intonacija, interjekcije...).

Od svih tekstova za prevođenje - prevodioci će se jednoglasno složiti - oni koji pripadaju književnoumjetničkome stilu su najzahtjevniji zbog naglašene emocionalnosti, izuzetne kompleksnosti, veće ili manje ikoničnosti te maksimalno izražene estetske komponente. Jezik književnosti se, znači, služi rafiniranim jezikom, a taj modifikator „rafinirani“ dobija još prestižnije i savršenije konotacije u jezicima svetih tekstova. Kur'an kao sveti tekst čije su poruke zgusnute i višedimenzionalne uopće ne dozvoljava potpuno dešifriranje, a kamoli onda ponovno šifriranje koje mu je vjerodostojno ogledalo. Izvorni arapski jezik na kom je pisan je toliko specifičan da je teško povući paralele između njega i savremenoga arapskog, a kamoli onda nekoga drugog jezika ili čak drugačijeg tipa jezika kakav je bosanski. Jednostavno rečeno: savršen jezički sistem + autor savršenog izrijeka $=$ gotovo neizvršiv zadatak za prevodioce.

\section{Modalne riječi i izrazi u svjetlu pragmalingvističkih i diskursnih studija}

Modalne riječi i izrazi su relativno dug period obitavale na marginama lingvističkih istraživanja iz razloga što tradicionalno orijentirani gramatičari nisu imali sluha za njih, a nisu zbog njihove „diskretne implementacije“ u sintaktičko i semantičko ustrojstvo rečenice. Naime, modalne riječi/izrazi nemaju ulogu rečeničnih dijelova niti su sa nekim od njih (bilo intonacijski, bilo sintaksički, bilo značenjski) čvrsto umrežene zbog čega se mogu reducirati bez štete po gramatičnost ili razumljivost rečenice. Međutim, pragmalingvističke i diskursne studije ${ }^{4}$ osvješćuju i

\footnotetext{
${ }^{4}$ Njemački lingvisti bi se mogli nazvati pionirima u izučavanju modalnih riječi što je sasvim razumljivo ako se uzme u obzir da njemački spada u red jezika sa najbogatijim fondom istih.
} 
dokazuju njihov neosporan $\mathrm{i}$ vitalan značaj koji možda nije evidentan u gramatici, ali u konkretnome govornom činu (tj. u komunikaciji) itekako jeste. Modalne riječi se tako počinju sagledavati iz jedne posve nove perspektive, kao podvrsta heterogene kategorije nazvane različitim imenima ${ }^{5}$ među kojima je najzastupljenije diskursne oznake. Diskursom smatramo kontekstualno uronjen tekst, a diskursnim oznakama indikatore te kontekstualizacije. One su, ustvari, jezički entiteti koji funkcioniraju kao komunikativna pomagala ili orijentiri (up. Harden 1983) kojima govornik sugerira sugovorniku kako će određeni iskaz interpretirati u odnosu na kotekst $^{6}$ (metatekstualna funkcija) ili u odnosu na kontekst ${ }^{7}$ (interakcijska funkcija). Metatekstualne diskursne oznake imaju za cilj signalizirati da je određeni iskaz vezan za neki drugi iskaz u diskursu i naznačiti prirodu te povezanosti od koje ovisi njegovo ispravno razumijevanje. $S$ druge strane, interakcijske diskursne oznake upućuju sugovornika kako će suziti raspoloživi kontekst (selektirati iz njega samo ono što je relevantno) i tako pokrenuti potrebne mentalne procese (tzv. inferencije) koji su zaduženi za pravilno i olakšano tumačenje iskaza. ${ }^{8}$ Imajući u vidu rečeno, modalne

\footnotetext{
${ }^{5}$ Pragmatičke/konverzacijske oznake, oznake tekstnih odnosa, diskursne/pragmatičke/modalne/iskazne partikule, (diskursni/pragmatički/rečenični/fatički) konektori, diskursne/vezne/konverzacijske riječi, rečenični prilozi., upućivačke fraze, diskursni/pragmatički/metalingvistički operatori, pragmatični/kohezivni uređaji,..

${ }^{6}$ Kotekst ili jezički kontekst je okruženje u kome se neka jezička jedinica (u ovom slučaju iskaz, ali to može biti i fonem i morfem i leksem) javlja. Uslovljen je interakcijom najmanje dvaju činilaca: odabirom pojedinih jedinica te njihovim sekvencijalnim redoslijedom uključujući tu i strukturne odnose među njima. Jezički kontekst, odnosno kotekst, nastaje u globalnom okviru nadjezičkog konteksta o kojem više u napomeni ispod (up. Prčić 2008: 33-34).

${ }^{7}$ Kontekst je mentalna kategorija, skup „svih saznanja i vjerovanja pohranjenih u sjećanju sudionika komunikacijskog procesa, ali je jednako tako zbir svih onih činjenica i znanja koje se mogu uočiti u neposrednoj situaciji, okružju ili jednostavno zaključiti na osnovu nečeg što je ranije rečeno" (Sperber i Wilson 1995 u Nigoević 2011a: 66).

${ }^{8}$ Diskursne oznake limitiraju inferencije, a ove stavljaju semantička ograničenja na eksplicitni sadržaj govornog iskaza (up. Blakemore 1992). Ovakvo shvatanje diskursnih oznaka vezujemo za teoriju relevantnosti.
} 
riječi ubrajamo u drugu potkategoriju. $\mathrm{Na}$ koji to način modalne riječi označavaju diskurs? One zapravo označavaju govornikov odnos prema propoziciji iskaza nastalom u određenoj situaciji, a samim tim i upustvo sugovorniku kako treba interpretirati taj isti iskaz u toj istoj situaciji i kakav bi stav prema njemu bilo poželjno da zauzme. Kako govornik i sugovornik skupa sa situacijom čine kontekst, a on je taj koji jedan tekst čini diskursom, modalne riječi/izrazi - uz konektore, interaktivne oznake i poštapalice $^{9}$ - doživljavamo kao znakove diskursa.

Ali zašto modalne riječi umjesto uobičajenog modalne partikule? Termin partikula je sam po sebi dosta „problematičan“ zato što iza njega stoji jedna posebna vrsta riječi koja se posljednja osamostalila i u koju se svrštavalo sve i svašta, a najčešće dvoje: sve nepromjenjive riječi ili sve riječi koje se ne mogu smjestiti niti u jednu od devet tradicionalnih vrsta riječi (ovom linijom su se u njima našle i modalne riječi/izrazi). Smatramo da u toj kategoriji treba uvesti reda tako što ćemo - za početak - iz nje izuzeti riječi i izraze koji služe za izražavanje odnosa prema izrečenom (vjerovatnost, mogućnost, nužnost), za naglašavanje i za povezivanje teksta (up. KarlićTušek 2013: 212). Drugim riječima, u kategoriji partikula ćemo ostaviti samo ono što većina lingvista smatra pravim partikulama/riječcama/česticama, a iz nje izuzeti sve ono što se obilježavalo sintagmom neprave partikule/riječce/čestice. Te dvije skupine su se dosad svodile pod isto na osnovu 3 kriterija: nepromjenjivost (kao da ovo svojstvo nije zajedničko i prijedlozima, veznicima, uzvicima te većini priloga), nepripadnost nijednoj drugoj vrsti riječi (kao da to uopće može biti kriterij) i modalnost. Modalnost jeste smislen kriterij a bio bi i

9 Sve tri kategorije imaju jednu od dvije prethodno iskazane funkcije diskursnih oznaka (koje se onda granaju u čitav splet podfunkcija), a dijele i neka formalna obilježja poput prozodijske samostalnosti, nepromjenjivosti, gramatičke opcionalnosti, distribucijske permutabilnosti te semantičke izlišnosti i neizdiferenciranosti/ nespecifiranosti (to bi značilo da ne ulaze u propozicijski sastav iskaza - odnosno ne utiču na istinosne uslove iskaza - dok je njihovo značenje ovisno o „konkretnim uslovima komunikacije“ zbog čega se često naziva pragmatičkim umjesto semantičkim). Sve su to razlozi zašto diskursne oznake i danas osciliraju između leksičkog i gramatičkog statusa. (up. Kordić 2002: 9 u Karlić-Tušek 2013: 208) 
dostatan da među modalnim riječima/izrazima i partikulama stavimo znak jednakosti, a ne možemo jer se tu ne radi o istoj vrsti modalnosti. Naime, one riječi koje mi smatramo partikulama - a drugi pravim partikulama služe za iskazivanje osnovne/intencijske rečenične modalnosti ${ }^{10} \mathrm{zbog}$ čega su sintaktički konstitutivne, ulaze u propozicijski sastav iskaza, krasi ih objektivnost i formalno im odgovaraju nazivi partikule/riječce/čestice („djelići“" govora) koji imaju deminutivan prizvuk jer se doista i radi o izuzetno kratkim riječima: da - ne, jest, kakvi, zar, (da) li, neka, deziderativno $d a, k a d \ldots . . S$ druge strane, modalne riječi i izrazi (za druge neprave partikule) su u službi modalnosti voluntativnosti i vjerodostojnosti/sigurnosti ${ }^{11}$ te su stoga sintaktički - ali ne i sintagmatski ${ }^{12}$ - samostalni, ne utiču na istinosne uslove iskaza, daju rečenici određeno subjektivno modalno obilježje i nema smisla da se nazivaju partikulama/riječcama/česticama kad među njima možemo naći ne samo višesložne nego i višečlane jezičke jedinice (npr. vjerovatno, čini mi se).$^{13}$ Međutim, u radu koristimo naziv partikule/čestice kada govorimo o modalnim riječima u arapskome jeziku zato što se u arapskoj jezičkoj tradiciji uvriježio naziv partikule/čestice za sve vrste nepromjenjivih riječi.

Za kraj modalne riječi/izraze određujemo kao sažete nadređene rečenice kojima se izražava govornikov stav o propoziciji iskaza (tj. prema stvarnosti) ili nekome njenom dijelu, a taj stav može biti: govornik jest ili

${ }^{10}$ Ova vrsta modalnosti je svojstvo svakog iskaza budući da je nužna za ostvarivanje predikacije, odnosno za formulaciju iskaza na izjavni, upitni, zapovjedni ili željni način. (Sesar 2001)

11 Intencijska modalnost obuhvata još dva gramatički neobavezna tipa modalnosti: modalnost vjerodostojnosti i voluntativnu modalnost. Prva označava stepen „sigurnosti ili nesigurnosti kazivača u istinitost, vjerodostojnost određene situacije“, a druga „izražava različite semantičke nužnosti, mogućnosti i namjere, odnosno kazivačevo mišljenje o uvjetima ostvarivosti neke situacije“. (Sesar 2001 : 205 i 206)

12 Njihova nesintagmatičnost proizilazi iz činjenice da ne mogu biti samostalni članovi sintagme niti se mogu sintagmatski povezati sa drugim rečeničnim dijelovima .

13 I pojedini poljski autori, kao što je npr. Zwolski (1985), razlikuju čestice na razini opće/rečenične modalnosti od posebne vrste riječi nazvane modulanatima. (up. Sesar 1992 i 2009) 
nije zadovoljan sadržajem iskaza, ubijeđen je ili sumnja u sadržaj iskaza, naglašava ili ublažuje sadržaj iskaza (ili kojega njegovog dijela).

\section{Jednosmjerna kontrastivna analiza}

Ovaj, glavni, dio rada započet ćemo iznošenjem osnovnih postulata interpretativne teorije prevođenja koja je - po našem mišljenju - jedina u stanju omogućiti najpribližnije ${ }^{14}$ prenošenje kur'anskog teksta iz arapskoga u neki drugi jezik.

Interpretativna teorija prevođenja ${ }^{15}$ počiva na prevođenju smisla a ne jezičke forme poruke iz čega proizlazi da interpretativni prevodilac ne traga za korespondencijama nego za ekvivalentima ${ }^{16}$. Vidić (2013: 110-112) navodi tri osnovne faze u procesu prevođenja: faza razumijevanja, faza deverbalizacije i faza reformulisanja (reverbalizacija). Prva faza podrazumijeva da prevodilac raspolaže svim potrebnim „kognitivnim prtljagom" (izvrsno poznavanje polaznog jezika te široko opće znanje) i „kognitivnim kontekstom“ (znanje proizašlo iz konteksta teksta koji se prevodi). Faza deverbalizacije se odnosi na prevodiočevu kognitivnu djelatnost koja materijalnu formu teksta pretvara u dematerijalizovano znanje i time mu omogućuje da od adresata postane adresant poruke. U zadnjoj fazi prevodilac smisao koji mu se ukazao u prethodnoj fazi zaogrće u novu jezičku formu i tako - ako se služi interpretativnom metodom uspostavlja globalnu ekvivalenciju između originalnog i prevedenog teksta, odnosno kroz ekvivalentnost forme prenosi identičnost sadržaja.

Drugim riječima, svaki prevoditelj mora ispravno protumačiti iskaz - to može samo ako u obzir uzme i rečeno i namjeravano (what is said i what

\footnotetext{
${ }^{14}$ Kur'an ne dozvoljava potpuno dekodiranje.

15 Utemeljena kao usmena teorija jezika, kasnije je naišla na dobar prijem i u pisanoj praksi.

16 Korespodencije predstavljaju odnos između dva jezična znaka u dva jezika, a ekvivalencije odnos između diskursnih jedinica. Ekvivalencije obuhvataju korespodencije ali ne i obratno.
} 
is meant $)^{17}$ - a potom njegovu propoziciju i ilokuciju, sa što manje ostatka, prenijeti u jezik na koji prevodi poštujući pritom koncepte interkulturalne komunikacije, odnosno uvažavajući jezičke sličnosti/različitosti koje su kulturološki uslovljene kao i ustaljene interakcijske sheme. Shodno tome zaključujemo da se uspjelim i vjerodostojnim prevodom smatra onaj kojim nije okrnjen smisao originalnog iskaza bez obzira da li su pritom korištena identična jezička sredstva, a ako jesu - tim bolje (up. Džanko 2010).

Prvi ajet sure koja će nam poslužiti kao korpus najbolji je pokazatelj da su prevodioci čiji rad ovdje sagledavamo (i na neki način procjenjujemo) uglavnom $^{18}$ korisnici interpretativne metode prevođenja. Naime, čisto jezički prijevod riječi elhakumu glasio bi zaokupljava vas, ali nisu je svi „naši“ prevodioci tom formom preveli (obuzela vas je tako - Karabeg, učinila vas je nehajnim i nemarnim - Čaušević i Pandža, odvraća vas Mlivo, zaokupljava vas do nemarnosti za ičim drugim - Duraković), a ipak su prenijeli manje-više isti smisao. Kod druge riječi (et-tekasur) interpretativni metod je još uočljiviji pošto ona doslovno znači gomilanje, a prevodioci su shodno svome enciklopedijskome znanju, poznavanju jezika s kojeg i na koji prevode te poznavanju konteksta (na osnovu brojnih tefsira Kur'ana) precizirali o kakvoj se vrsti gomilanja radi i to u vidu sintagmi najrazličitijeg sastava i duljine, ali opet dosta sličnog smisla:

\section{Elhahukumut-tekasur}

Želja za umnožavanjem obuzela vas je tako, (Karabeg)

Želja da uvećate vaše bogatstvo $i$ hvalisanje mnoštvoom imetka, učinila vas je nehajnim i nemarnim (Čaušević - Pandža) Zaokuplja vas nastojanje da što imućniji budete (Korkut) Odvraća vas uvećavanje, (Mlivo) Zaokuplja vas nadmetanje u zgrtanju imetka ( Karić)

\footnotetext{
17 To znači da prevodilac ne prevodi samo ono što je autor teksta eksplicitno dao do znanja, nego i ono pozadinsko što hotimično nije izrekao, ali je dao naslutiti.

${ }^{18}$ Doduše, možda to ne možemo tvrditi za Mlivu.
} 


\section{Uzgrtanju nehajni postajete, (Duraković)}

\section{Zaokuplja vas zgrtanje imovine (Mehanović)}

Ovo je jedini ajet sure Et-Tekasur u čijem originalu nema niti jedne čestice, ali ima u Korkutovom prijevodu modalna riječ što koja je „svojevrsni pojačivač poredbenih (usporednih) značenja“ (up. Pranjković 2009: 332). Korkut ju je iskoristio u graduiranju onog čemu je domeće pridjevu imućniji. ${ }^{19}$ Sličnu ulogu ima sve u narednome, tj. drugome, ajetu kada se prilaže čestici hatta (dok) koja uvodi iskaz čijim se sadržajem okončava sadržaj iskaza koji mu je prethodio ${ }^{20} \mathrm{i}$ to tako da dodatno osigurava kako između radnji u njima nema ni najmanje „praznog prostora" pošto jedna dokida drugu:

\section{Hatta zurtumul-mekabir.}

da vas ta želja prati do grobova vaših. (Karabeg)

sve dotle dok ne posjetite grobove. (Čaušević - Pandža)

sve dok grobove ne naselite. (Korkut)

Dok greblja ne posjetite. (Mlivo)

sve dok grobove ne posjetite! ( Karić)

Sve dok mezare ne pohodite. (Duraković)

sve dok mezarja ne posjetite. (Mehanović)

\section{Kella}

Čestica kella u arapskome jeziku ima najmanje pet funkcija: 1. izražavanje prijekora, pogrde i osude koja se odnosi na sadržaj prethodnog ili - dosta rjeđe - narednog segmenta (Kella la ne valja takol, zapisat ćemo śta on kazuje.); 2. izražavanje čvrste, pojačane, negacije (Kella /nikakol, po sto puta kella /nikako!!); 3. davanje odgovora kojim se potvrđuje određena činjenica

\footnotetext{
19 Sto sa ovom funkcijom se prilaže komparativu ili superlativu pridjevai priloga.

${ }^{20}$ To je samo jedna od njegovih funkcija jer on, naprimjer, može stajati između iskaza u kojima se odvijaju paralelne radnje: Danas sam toliko toga uradio. Dok si se ti izležavao, naravno.
} 
ili ustanovljava ono što je istinito i ispravno ( $A$ što je ona do opomena ljudima?! Kella lupravo takol, tako Mi Mjeseca!); 4. skretanje pažnje (Kella Iglel, čovjek se zaista uzobijesti.); 5. izražavanje upozorenja za koje se najčešće već unaprijed zna da po svoj prilici neće imati učinka na recipijenta (A: Izaći ću večeras bez obzira śta se dogodilo! - B: Kella Ini u kom slučajul!). (up. Ez-Zemahšeri 2001: IV,798; Ebul-Azm 2001: IV, 317; Unejs i dr. 1972: II, 797). Sada ćemo vidjeti kako se to kella „ponaša“ u odabranome korpusu:

3. Kella, sevfe ta'lemun!

Ali neka, znaćete vi udes takoga držanja!

Nije li tako, vi ćete brzo saznati (u grobu),

A ne valja tako, saznat ćete svakako!

Nikako! Saznaćete!

$A$, doista, ne valja tako, saznat ćete svakako!

Ne! Jer, vi ćete saznati,

A ne treba tako, saznat ćete svakako!

4. Summe, kella, sevfe ta'lemun!

I opet ćete znati udes takoga držanja.

zatim, sigurno ćete skoro saznati (na Sudnjem danu).

i još jednom, ne valja tako! Saznat ćete sigurno!

Ponovo ne, saznaćete!

i opet, zbilja, ne valja tako, saznat ćete svakako!

Još jednom: Ne tako! Vi ćete saznati:

I još jednom, ne treba tako! Saznat ćete sigurno!

21 Prijevodi svakog ajeta u radu idu sljedećim rasporedom: (Karabeg), (Čaušević Pandža), (Korkut), (Mlivo), (Karić), (Duraković) i (Mehanović). 
Čestici kella su - kako smo maloprije ustvrdili - svojstvene brojne funkcije, a u trećem ajetu aktualizirana je njena prva funkcija (među gore pobrojanim) s tim da ne isključujemo ni petu. $\mathrm{U}$ arapsko-bosanskome rječniku se navode sljedeći ekvivalenti za natuknicu kella: nikako, nipošto, naprotiv (Muftić 1997: 1305), dok prevodioci sa arapskog na bosanski jezik nerijetko upotrebljavaju i ekvivalente: gle, ne valja tako, zar n(ij)e?, ni u kom slučaju, ni po koju cijenu, ni slučajno... Vidimo da su „naši“ prevodioci ovdje posegnuli za dosta različitim prijevodnim rješenjima što je posve razumljivo jer u bosanskome jeziku ne postoji jedna (jedinstvena) modalna riječ da objedini sve funkcije koje kella pokriva u arapskome. No, ono što je zajedničko svima njima (osim Mlivi i Durakoviću) jeste da su je preveli koristeći višečlane jezičke jedinice u čijem sastavu mogu biti modalne riječi, ali i ne moraju. Korkut i Mehanović nude gotovo iste ekvivalente $I A$ ne valja tako i $A$ ne treba takol, kratke rečenice sa konektorom ili bolje rečeno intenzifikatorom u inicijalnoj poziciji ${ }^{22}$ - koje izražavaju prijekor/pogrdu/osudu kroz koju kao da provijava doza razočarenja ${ }^{23}$; Karić tu „predmeće“ jedno doista koje je istovremeno potvrđuje i pojačava / $A$, doista, ne valja tako/, Mlivo i Duraković su odveć kategorični (tako da doza razočarenja izostaje) i pomalo doslovni /Nikako i $\mathrm{Ne}$ /; Korkut sa dopunom u zagradi / Nikako (to ne valja)/ kao da prva tri, odnosno dva, prijevodna rješenja objedinjuje; ekvivalent koji su ponudili Čaušević - Pandža po svoj prilici nema za cilj osudu/prijekor/pogrdu nego dokazivanje /Nije li tako/. Karabegov prevod (Ali neka) smo ostavili za kraj iz razloga što ga smatramo u većoj mjeri adekvatnim nego ostale, a sad ćemo obrazložiti zašto. Mrazović (2009) među skupinom konverzacijske partikule navodi i neka koje ima niz funkcija (izražavanje blagosiljanja, kletve/proklinjanja, želje, blagog odbijanja...), a među njima i tri koje su nama ovdje od značaja: iskazivanje mirenja sa nečim (Razbila sam čašus. -

${ }^{22} A$ je ovdje prevashodno adverzativni konektor koji povezuje iskaze kontrarnoga sadržaja (vi to/tako radite, a to/tako ne valja ili ne treba raditi), međutim on pored te povezničke funkcije ima i funkciju isticanja dispariteta među spornim iskazima ili pak naglašavanja posebnosti sadržaja iskaza u čijem je sastavu pa bi ga bilo najbolje nazvati „konektivno-intenzifikatorskom riječju“ (up. Abović, 2010:50-55)

${ }^{23}$ Isti bi se učinak postigao kada bi se umjesto $a$ upotrijebilo eee. 
Neka, dijete, kupit ćemo drugu.) te iskazivanje prijekora/prebacivanja i prijetnje (Neka, neka, a ja sam tebi pomogla kad je trebalo! ili Neka, neka, vidjet ćemo se mi jošs.). Karabegovo prijevodno rješenje uistinu eksplicira ravnodušnu rezignaciju jer je u Allahovoj moći sve ljude učiniti vjernicima samo ako to hoće, ali ako ga se pomno razmotri, primjećujemo da istovremeno implicira i prijekor uz primjesu razočarenja. No, pomenuta autorica prijekor/prebacivanje i prijetnju navodi kao funkcije neka samo u slučaju da je udvojeno, ali Karabeg umjesto udvajanja koristi intenzivirajuću modalnu riječ ali koja - po našemu mišljenju - to udvajanje ne može potpuno nadomjestiti. Zato predlažemo ekvivalent neka, neka koji nema identičan fond funkcija kao i arapska čestica kella, ali zato ima gotovo sve koje su aktualizirane o ovome ajetu: prijekor, osuda, pogrda i upozorenje za koje onaj koji ga izdaje zna da neće biti učinkovito pa ga se slobodno može shvatiti kao prijetnju. Zasad nam se ovo čini jedinim ekvivalentom koji isijava onu oštrinu koju kella nosi u sebi.

5. Kella, lev ta'lemune i'lmel-jekin...!?

$\mathrm{Nu}$, varate se! Da znate vi čvrstim znanjem ne biste se bavili praznim hvalisanjem. (Karabeg)

Da, da, kad biste vi potpuno i sigurno znali (sta je pred vama). (Čaušević - Pandža)

Ne valja tako, neka znate pouzdano, (Korkut)

Nikako! Kad biste znali znanjem sigurnim! (Mlivo)

Ne valja tako, nek'znate jamačno, (Karić)

Ne! Trebali biste pouzdano znati: (Duraković)

Ne valja tako, kada biste vi znali pouzdano, (Mehanović)

Iako je riječ kella $\mathrm{u}$ istom značenju ( $\mathrm{tj}$. sa istom funkcijom) upotrijebljena u četvrtome i petome ajetu koje smo također iznad ponudili, u četvrtome je Karabeg i Čaušević - Pandža uopće ne prevode najvjerovatnije da izbjegnu dojam „pretrpanosti“ pošto joj prethodi čestica summe. Međutim, ako se iznađe adekvatan prijevod za summe, kella se može prevesti istim ekvivalentom kao u prethodnome ajetu, a da se pritom ništa ne doima 
viškom. Tako su, otprilike, postupili ostali prevodioci - kažemo „otprilike“ zato što su ekvivalente iz prethodnog ajeta na neki način kontrahirali, odnosno skratili, ali bez veće štete po značenje: a ne valja tako > ne valja tako (Korkut), nikako > ne (Mlivo), a, doista, ne valja tako > zbilja, ne valja tako (Karić), a ne treba tako > ne treba tako (Mehanović) osim Durakovića koji ju je „obogatio“ prilogom ( $N e>N e$ tako). Oni i u petome ajetu ostaju koliko-toliko dosljedni kada prevode ovu riječ (ponavljaju ekvivalent iz trećega ili pak četvrtoga ajeta), ali Karabeg i Čaušević - Pandža sada umjesto nultim prevode vrlo neobičnim ekvivalentima (Karabeg rečenicom $\mathrm{Nu}^{24}$, varate se!, a Čaušević - Pandža udvojenom česticom $d a$ ) u kojima opet dolazi do izražaja interpretativna prijevodna tehnika ili pak sloboda prevođenja ${ }^{25}$. Mi i dalje ostajemo kod „našeg“ neka, neka! koje i u ovome ajetu ima iste pragmatične učinke kao u prethodna dva samo što dobija još jaču ilokucionu snagu budući da je u inicijalnoj poziciji eliptičnog iskaza (Neka, neka, kad biste vi samo znali...). Uostalom, ni u originalu nije upotrijebljena neka druga čestica premda ih arapski jezik ima u izobilju što znači da je njena selekcija hotimična (nekim ljudima potpuno istu stvar treba ponoviti po nekoliko puta da bih do njih doprijela.

\section{2. Sevfe}

Sintaksičari arapskoga jezika sevfe definiraju kao česticu koja aludira na ono čemu idemo u susret (ar. harful-istiqbal), odnosno kao partikulu koja pripomaže $u$ iskazivanju budućeg vremena, a ona taj svoj zadatak može vršiti na tri načina: 1 . označavajući da će se neka radnja desiti u budućnosti (tipična tvorba futura); 2. garantirajući za izvršenje određene radnje u budućnosti, pa makar trenutno ne postoje nikakve indicije ni za početak njezinog odvijanja; 3. aludirajući - uz jamstvo ili bez njega - da će se dotična radnja odigrati nakon pozamašnog perioda, dakle u dalekoj budućnosti. Kada sevfe „sigurira“ za neku radnju (bilo kod prvog, bilo kod drugog načina), može se protumačiti kao prijetnja (Sevfe /zaistal ćete se

\footnotetext{
${ }^{24} \mathrm{Nu}$ je stilski markirano i stvarno iznenađuje njegovo pojavljivanje ovdje.

${ }^{25}$ Prevodilac može sebi dopustiti izvjesnu slobodu u prevođenju, ali samo ako ona neće rezultirati prepričavanjem ili adaptacijom originalnog teksta (Vidić 2013: 120-121).
} 
uvjeriti!) ili obećanje (A Gospodar tvoj će tebi sevfe /sigurnol dati pa ćeš zadovoljan biti). Nije neobično da joj se dometne čestica le kako bi se ta uvjerenost dodatno osnažila (up. El-Asfehani 1997: 436; Unejs i dr. 1972: 464; El-Eškar 1995: 236). Vraćamo se ponovo trećem ajetu sure Et-Teksur ali ovaj put $s$ akcentom na česticu sevfe (umjesto na kella) i uz njega prilažemo četvrti ajet u kom se ta čestica upotrebljava u istome značenju:

3. Kella, sevfe ta'lemun!

Ali neka, znaćete vi udes takoga držanja!

Nije li tako, vi ćete brzo saznati (u grobu),

A ne valja tako, saznat ćete svakako!

Nikako! Saznaćete!

$A$, doista, ne valja tako, saznat ćete svakako!

Ne! Jer, vi ćete saznati,

A ne treba tako, saznat cete svakako!

4. Summe, kella, sevfe ta'lemun!

I opet ćete znati udes takoga držanja.

zatim, sigurno ćete skoro saznati (na Sudnjem danu).

i još jednom, ne valja tako! Saznat ćete sigurno!

Ponovo ne, saznaćete!

i opet, zbilja, ne valja tako, saznat ćete svakako!

Još jednom: Ne tako! Vi ćete saznati:

I još jednom, ne treba tako. Saznat ćete sigurno!

Muftić (1997) uz lemu sevfe ne stavlja ekvivalente već navodi primjer upotrebe sevfe tera i prevodi ga sa vidjet će što znači da na nju gleda isključivo kao na česticu za iskazivanje budućeg vremena, bez ikakvih dodatnih indicija. Očito da su istog mišljenja Karabeg, Mlivo i Duraković čiji prijevodi ove čestice i riječi uz koju stoji u oba ajeta glase znaćetelćete znati i saznaćetelćete saznati (nesvršeni i svršeni oblik glagola). Ako je suditi 
po njihovome prijevodu, Korkut, Karić i Mehanović u riječi sevfe pored gramatičke uočavaju i modalnu funkciju. Riječ sevfe doista jeste - prije svega - pomoćna riječ koja služi pri tvorbi futura, ali je i riječ kojom se obznanjuje i naglašava kazivačeva uvjerenost u tačnost iskazanog i kojom se pokušava isti dojam izazvati kod recipijenta. Upravo zbog tako obuhvatnog shvatanja namjene riječi sevfe, smatramo adekvatnima ekvivalente pomenute trojice prevodioca jer su iskombinirali oblike saznat ćetelćete saznati s modalnim riječima svakako i sigurno ${ }^{26}$ koje ubrajamo u sredstva za izražavanje modalnosti vjerodostojnosti/sigurnosti i u sredstva za isticanje (up. Sesar 2009: 53). Da budemo precizniji, riječi svakako i sigurno izražavaju najveći mogući stepen sigurnosti (potpuna, neupitna, neprikosnovena sigurnost) i „najjači mogući domet pojačanja“27, a upravo se takve za ovaj ajet traže da bi se pomoću njih u vidu prijetnje, zastrašivanja i obećanja potvrdilo - ili bolje reći garantiralo - izvršenje dotične radnje ne bi li recipijenti spoznali opomenu koja im se implicira. Međutim, riječima svakako i sigurno se ne može pripisati funkcija vremenskog limitiranja jer one ničim ne pretendiraju da ograniče duljinu razdoblja koje treba proći kako bi se ono što je obećano ili ono čime je zaprijećeno obistinilo, a Čaušević - Pandža tu vremensku dimenziju, čini se, smatraju bitnijom od modalne pa koriste prilog brzo u 3. ajetu da bi dali do znanja kako će se dotična radnja desiti u skorijoj budućnosti (u grobu), a prilog skoro u 4. ajetu ne bi li označili kako se izvršenje sporne radnje može očekivati u daljoj budućnosti (na Sudnjem danu).

\section{3. Summe}

4. Summe, kella, sevfe ta'lemun!

I opet ćete znati udes takoga držanja.

zatim, sigurno ćete skoro saznati (na Sudnjem danu).

\footnotetext{
${ }^{26}$ Korkut i Mehanović u ajetu broj tri upotrebljavaju svakako a u ajetu broj četiri sigurno, pretpostavljamo radi stilskog razjednačavanja. Karić je u oba ajeta upotrijebio isti ekvivalent (svakako) što nam se čini ispravnijim jer ni $\mathrm{u}$ arapskome nema razlike $\mathrm{u}$ formama pošto se radi o ponavljanju.

27 (Nigoević 2009)
} 
i još jednom, ne valja tako! Saznat ćete sigurno!

Ponovo ne, saznaćete!

i opet, zbilja, ne valja tako, saznat ćete svakako!

Još jednom: Ne tako! Vi ćete saznati:

I još jednom, ne treba tako. Saznat ćete sigurno!

7. Summe, letervunneha ajnel-jekin!

I opet ćete ga očevidno vidjeti!

I zatim ćete ga nesumnjivo vidjeti svojim očima,

I još jednom, doista ćete ga vidjeti očigledno!

Ponovo, zaista ćete ga vidjeti okom sigurnim,

i opet, zbilja ćete ga vidjeti očigledno!

I još jednom: Sigurno ćete ga svojim očima vidjeti;

I još jednom, doista ćete ga vidjeti sasvim jasno!

Arapski sintaksičari summe određuju kao čestični veznik s mnoštvom funkcija među kojima ćemo izdvojiti slijedeće: 1 . označava hronološki tok (npr. Zejd nam je prvo došao u posjetu, summe la potom/ je otputovao na hadž.); 2. iskazuje hijerarhijski poredak (Došlo je do mene šta su uradio danas, ali summe lopet, ono što si uradio jučer je fascinantnije.); 3. graduira - uzdiže na veći stepen sadržaj koji dolazi poslije nje ili pak pojačava ono što je kazano prije nje (up. El-Eškar 1995: 158). U četvrtome i sedmome ajetu ovdje tretirane sure aktualizirana je upravo ta zadnja funkcija kada summe potcrtava, pojačava i potvrđuje prethodno iskazane sadržaje (3. Neka, neka, saznat ćete vi, sigurno! i 6. Uistinu ćete vidjeti Džehennem!) i to tako što uvodi, tj. najavljuje, njihovo (gotovo) doslovno ponavljanje:

Po prijevodima vidimo da je tu funkciju prepoznala i većina prevodioca: Korkut, Mehanović i Duraković nude ekvivalent (i) još jednom ${ }^{28}$, Mlivo

28 Duraković prvo summe u suri prevodi još jednom, a drugo $i$ još jednom što je odlično rješenje jer na taj način lahko i logično vrši gradaciju. 
ponovo, Karić $i$ opet. Izraze $i$ opet te $i$ još jednom smatramo adekvatnim iz razloga što je u njihovom sastavu uistinu zanimljiva i primjerena kombinacija - s jedne strane diskursna oznaka $i$ kojoj je svojstven čitav splet funkcija koje summe vrši u ajetima iznad: povezuje iskaze čiji smisao ide u istom smjeru (smjer razvijanja glavne teme), ukazuje na sličnost sadržaja između dva susjedna iskaza, nadodaje na prethodno rečeno, pojačava ono što je prethodilo onim što će uslijediti; s druge strane opet i još jednom koji signaliziraju ponavljanje. Karabeg je također preveo sa $i$ opet, ali izostavljanjem zareza i distribucijom enklitike (ćete u antepoziciji) stilistiku je podredio gramatici - po njemu ovdje nije u pitanju intenzifikacija nego količinski odnos. Čaušević - Pandža summe u ovim ajetima sagledavaju iz posve druge perspektive, vremenske perspektive koja je zapravo prisutna u narednome ajetu:

8. Summe, letuselunne jevme izin a'nin-neim!

Nakon toga bićete pitani za (ovosvjetske) blagodati. (Karabeg)

a poslije toga ćete sigurno biti pitani onoga Dana, za sva svoja uživanja. (Čaušević - Pandža)

Zatim ćete toga dana za sladak život biti pitani sigurno! (Korkut)

Zatim ćete zaista Tog dana o uživanju pitani biti. (Mlivo)

a potom ćete, toga Dana, za slatki život pitani biti, pouzdano! ( Karić)

Potom ćete - toga Dana - za uživanje odgovarati.(Duraković)

Zatim ćete Dan taj o blagodatima biti pitani sigurno! (Mehanović)

S našom zadnjom konstatacijom se slažu svi jer je evidentno da summe sada ima za cilj povezati dva iskaza po principu sukcesivnosti ne precizirajući pritom vremenski razmak između realizacije radnji koje se u njima nagovještavaju. Da je ova hronološko-konektorska funkcija frekventnija od ostalih dokazuje omjer njenih i njihovih ekvivalenata u arapskobosanskome rječniku: tada, onda, zatim, potom, pa, i opet (Muftić 1997: 186). 


\section{4. Lev}

Lev je u osnovi čestica za uslovljavanje, odnosno veznik pogodbenih rečenica, koji se prevodi sa $d a$ ako je u pitanju tvorba prošlih i sadašnjih pogodbenih rečenica (A lev ldal je Allah htio, on bi im oduzeo i sluh $i$ vid. ili Lev /dal Allah hoće, svi bi ljudi bili vjernici), a sa ako i kad u slučaju da je posrijedi tvorba budućih pogodbenih rečenica (Lev /kad/ stigneš, dobit ćeš. ili I neka se poboje oni koji bi strahovali za svoju nejaku djecu lev lako/ bi ih ostavili same iza sebe). ${ }^{29}$ Postoje još tri funkcije čestice lev koje se - po mišljenju nekih gramatičara - mogu podvesti pod ovu pogodbenu: 1 . izražavanje želje i potrebe (Lev /dal sam bio s njima, pa da budem među pobjednicima.); 2. iznošenje ponude (Lev løl dođi nam, mnogo ćeš dobra steci.); 3. iskazivanje namjere (Svaki od njih bi volio lev ldal poživi hiljadu godina.). Pojedini lingvisti dodaju još jednu funkciju - funkciju graduiranja i to isključivo u svrhu minimiziranja: Udijelite milostinje, lev lbar ili makar i/ jednu hurmu (up. Unejs i dr. 1972: II, 844). No, nas zanima ta njegova primarna funkcija (uvođenje zavisne pogodbene rečenice) i to u jednoj specifičnoj situaciji: zavisna rečenica eksplicirana glavna rečenica izostavljena radi što intenzivnijeg impresioniranja recipijenta. Drugim riječima, lev ima veliki stilistički i pragmatički potencijal kada njime počinje iskaz kojim se izražava uslov, ali zatajuje radnja koju uslovljava ne bi li se recipijent angažirao i dopunio prazninu (up. Es-Sujuti 2004: I, 371; Ez-Zemahšeri 2001:IV, 799; Abbas 2001: 260), a upravo takvo što donosimo u ajetu ispod:

5. Kella, lev ta'lemune i'lmel-jekin...!?

$N u$, varate se! Da znate vi čvrstim znanjem ne biste se bavili praznim hvalisanjem. (Karabeg)

$D a, d a, k a d$ biste vi potpuno i sigurno znali (sta je pred vama). (Čaušević - Pandža)

Ne valja tako, neka znate pouzdano, (Korkut)

Nikako! Kad biste znali znanjem sigurnim! (Mlivo)

${ }^{29}$ Muftić je prevodi kao da, kad, daj, hajde (1997:1369). 
Ne valja tako, nek' znate jamačno, (Karić)

Ne! Trebali biste pouzdano znati: (Duraković)

Ne valja tako, kada biste vi znali pouzdano, (Mehanović)

Karabeg jedini primjećuje taj pragmatični učinak i čak pokušava rekonstruisati izostavljeno po svome nahođenju, vjerovatno pod uticajem mufesira i vlastitoga iskustvenog znanja u kome je pohranjeno da jaka žudnja za velikim imetkom obavezno rezultira hvalisanjem i oholjenjem ako je se zadovolji, a to je hvalisanje isprazno jer u konačnici čovjek sve ostavlja iza sebe i ničim materijalnim se ne može okoristiti poslije smrti. Korkut i Karić svojim ekvivalentima neka i nek' jasno daju do znanja da ovdje ne uočavaju nikakvu pogodbu nego naglašenu imperativnu konstataciju. Kod Durakovića je ista situacija samo bez imperativnog tona (prije konstatirajućeg). Čaušević - Pandža, Mlivo i Mehanović sagledavaju lev kao česticu kojom započinje iskaz u kom se nudi uslov, ali po interpunkciji (zarez) zaključujemo da ne uviđaju redukciju uslovljene radnje nego je pronalaze u idućem ajetu. ${ }^{30}$

\section{5. Le in (lit-tek'id)}

Funkcionalnost, $\mathrm{tj}$. upotreba, čestice le je izuzetno velika: koristi se za izricanje padežnih značenja (up. Unejs i dr. 1972: II, 809), za tvorbu imperativa, služi kao zakletva ili sredstvo isticanja pripadništva nečemu, upotrebljava se radi pojašnjenja, specificiranja, kao potvrda negacije ili kao (potvrdni) odgovor na pogodbenu česticu in (bos. ako), dolazi kao intenzifikator onoga što će uslijediti iza potvrdne čestice inne postavljene ispred subjekta ${ }^{31}$... (up. Ebul-Azm 2001:491). Međutim u njene krucijalne

\footnotetext{
30 Sintagma ilmul-jekin prevedena je na dva načina:

a) pridjev (čvrst, pouzdan) + imenica (znanje) kod Karabega i Mlive,

b) prilog (potpuno, sigurno, pouzdano i jamačno) + glagol (znati) kod ostale peterice. Badurina (2008) smatra da su sigurno i jamačno komutabilni, ali da se jamačno u upotrebi udaljava od potpune sigurnosti i semantički priblažava ka vjerovatno, zacijelo, po svemu sudeći.

$31 \mathrm{U}$ našem jeziku se ovo le prevodi nultim ekvivalentom jer bi svaki drugi ekvivalent djelovao suvišno:
} 
funkcije ubrajamo dvije: kada se le nađe ispred predikata, potvrđuje odvijanje određene radnje, a ako se nađe ispred nekog drugog rečeničnog člana, osnažuje ga: Le /zaistal je ružno to što su oni radili (up. Ez-Zemahšeri 2001: IV, 799; Es-Sujuti 2004: I,365; Bint Šati 1990: I, 206; El-Eškar 1995: 346). U ta dva slučaja čestica le se prevodi u značenju doista, zaista, uistinu, sigurno (Muftić 1997: 1325).

Čestica $n$ (nun et-te'kid) se prevodi u značenju sigurno, svakako jer ima funkciju partikularnog pojačavača predikata (Muftić 1997: 1453). Ona se, naime, u vidu nastavka dodaje glagolu u futuru (ili u futurističkom i svevremenskom prezentu) kako bi ustvrdila te kod recipijenta pojačala i potvrdila dojam da će se dotična radnja odviti ${ }^{32}$ : Nemojte računati $n$ Inipoštol da je Allah nemaran! (up. Es-Sujuti, 2004: I, 379. i Bint Šati, 1990: I, 206). Ovdje je njena upotreba fakultativna, a nakon zakletve je obavezna: Tako mi Allaha, ja ću doista napakostiti (lekidenne) vašim kumirima nakon sto se okrenete i udaljite (Unejs i dr. 1972: II, 895).

Kad se želi stopostotno zajamčiti izvršenje određene radnje u budućnosti, čestice le i $n$ se kombiniraju tako što se le predmeće, a $n$ domeće glagolu baš kao što je slučaj u posljednja tri ajeta sure Et-Tekasur:

\section{Leterevunnel-džehim!}

Uistinu, vidjećete pakao! (Karabeg)

vi biste zaista vidjeli pakao. (Čaušević - Pandža)

Džehennem ćete vidjeti jasno! (Korkut)

Zaista ćete vidjeti džehim; (Mlivo)

džehennem ćete vidjeti sigurno! (Karić)

Sigurno ćete Džehennem vidjeti; (Duraković)

Oganj ćete, zaista, vidjeti! (Mehanović)

Inne /zaistal je Gospodar moj, le løl onaj koji čuje molbe!

Inne /zaistal Gospodar tvoj, le løl presuduje izmedu njih.

Inne /zaistal si ti, na le løl najvećem stepenu ćudoreda!

32 Es-Sujuti, 2004, tom I, str. 379. 
7. Summe, letervunneha ajnel-jekin!

I opet ćete ga očevidno vidjeti!

I zatim ćete ga nesumnjivo vidjeti svojim očima,

I još jednom, doista ćete ga vidjeti očigledno!

Ponovo, zaista ćete ga vidjeti okom sigurnim,

i opet, zbilja ćete ga vidjeti očigledno!

I još jednom: Sigurno ćete ga svojim očima vidjeti;

I još jednom, doista ćete ga vidjeti sasvim jasno!

8. Summe, letuselunne jevme izin a'nin-neim!

Nakon toga bićete pitani za (ovosvjetske) blagodati. (Karabeg)

a poslije toga ćete sigurno biti pitani onoga dana, za sva svoja ǔ̌ivanja. (Čaušević - Pandža)

Zatim ćete toga dana za sladak život biti pitani sigurno! (Korkut)

Zatim ćete zaista Tog dana o uživanju pitani biti. (Mlivo)

a potom ćete, toga Dana, za slatki život pitani biti, pouzdano! (Karić)

Potom ćete - toga Dana - za uživanje odgovarati! (Duraković)

Zatim ćete dan taj o blagodatima biti pitani sigurno! (Mehanović)

Kada se ove čestice prevode ponaosob na bosanski jezik, imaju otprilike iste ekvivalente, ali ako su udružene, onda je najprimjerenije koristiti jedan ekvivalent za obje jer bi dva istovrsna potvrđujuća modaliteta u jednom iskazu bila previše. Evo šta o tome misle naši prevodioci: Karabeg u šestom ajetu $l e+n$ prevodi (jednim) ekvivalentom uistinu, a u sedmom i osmom ih uopće ne prevodi; Čaušević - Pandža dotičnu kombinaciju u šestom ajetu prevode sa zaista, u sedmom je ne prevode nikako, a u osmom sa sigurno; Korkut u šestom ajetu nudi nulti ekvivalent (jasno ovdje shvatamo kao prilog), u sedmom doista, a u osmom sigurno; Mlivo u sva tri ajeta prevodi ove pojačivače ekvivalentom zaista; Karić ih također prevodi u svakom ajetu i to sljedećim redoslijedom: sigurno, zbilja, pouzdano; Duraković ih u šestome i sedmome ajetu prevodi modalnom riječju sigurno 
dok ih u posljednjem ajetu zanemaruje; Mehanovićeva prijevodna rješenja glase: zaista, doista, sigurno.

Vidimo da ovdje ne postoje dva prevodioca između čija sva tri prijevodna rješenja možemo staviti znak jednakosti, ali neke stvari su ipak većini zajedničke: ako prevode sporne modalitete, prevode ih isključivo riječima zaista, doista, uistinu, ${ }^{33}$ sigurno i pouzdano koje potvrđuju bezrezervnu istinitost i „pojačavaju kategoričke afirmacije“ iako bosanski jezik posjeduje čitavu paletu takvih riječi/izraza; svi oni (osim Mlive) pribjegavaju razjednačavanju pa tako u svakom ajetu koriste drugačije ekvivalente; modalitete uglavnom ne omeđuju zarezima (ili ako to čine, nisu dosljedni) što izaziva dvosmislenost (up. Tekavčić 1989).

\section{Zaključak}

Kur'anski diskurs obiluje „potvrđujućim i pojačavajućim modalitetima“, a sura Et-Tekasur je - s obzirom na svoju veličinu - jedna od njima najzasićenijih: u samo osam ajeta savršeno se uklopilo čak četrnaest modalnih riječi a njihov broj u prijevodima na bosanski jezik varira od sedam do šesnaest baš kao što varira stepen njihove stilske ukomponiranosti u tekst, od prevodioca do prevodioca. Modalne čestice kella, sevfe, summe, lev, le i $n$ djeluju u dva pravca: iskazuju autorovu čvrstu uvjerenost u ono što je trenutno a čime On nije zadovoljan ili pak iskazuju autorovu čvrstu uvjerenost u ono što nadolazi a čime oni (recipijenti) neće biti zadovoljni. Drugim riječima, njihova uloga je da kore, ali i da zastrašuju i opominju. Pošto je smisao Kur'ana dokraja nedosezljiv, a izvorni arapski jezik izuzetno kompleksan i mističan, prevodioci su se našli pred nimalo lagahnim zadatkom - valjalo im je pokušati proniknuti u smisao Božanskih riječi te iznaći prijevodna rješenja koja će biti i funkcionalna i estetska (ona koja će izvršiti približan pragmatični učinak, a usto još odgovarati uobičajenim formama izražavanja u bosanskome jeziku kako bi se izbjegao dojam sirovosti). Do pojmovne suštine modalnih riječi je veoma teško prodrijeti, a ako se i uspije, time je samo jedna poteškoća savladana, druga - još veća - tek predstoji. Naime, arapski i

${ }^{33}$ Ove prve tri riječi čak imaju istinu za etimološko značenje. 
bosanski jezik nemaju identično razvijen sistem modalnih riječi baš kao što ni modalne riječi prisutne u oba jezika ne raspolažu istim inventarom funkcija zbog čega je katkada potrebno posegnuti za raspoloživim jezičkim sredstvima potpuno drugačije prirode u svojstvu što približnijih ekvivalenata. To su, ovdje tematizirani, prevodioci i činili (manje-više uspješno) sa česticom kella koja je po našem mišljenju „najkritičnija“ budući da nijedna modalna riječ bosanskoga jezika ne posjeduje njen pragmatički kapacitet i stilski efekt. Čestica $n$ je jedina kod koje smo stali na stranu nultog ekvivalenta jer je svaki drugi u iskazu bio pleonastičan. Oko ostalih čestica (sevfe, sume, lev, le) je bilo manje spora. Prevodiocima nisu mogla biti od pomoći tada raspoloživa leksikografska djela baš kao što ne bi bili ni današnji b/h/s rječnici jer u njima se za modalne riječi još uvijek navode samo sinonimi bez detaljnog ispisivanja i opisivanja funkcija kako je to u praksi nepremašnih arapskih leksikografa. $S$ druge strane, nama i čitaocima prijevoda su pojedini prevodioci odmogli svojom nedovoljnom angažiranošću oko bilježenja zareza u svrhu razgraničavanja modalnih riječi od priloga.

\section{Literatura:}

1. Abbas, Fadl (2005). El-Belaga - fununuha ve efnanuha. Amman: DarulFurkan.

2. znanstveni problem $O$ prirodi veznika a i mogućnosti komutabilne upotrebe veznika a i i. Lingua Montenegrina, III/5. str. 47-60.

3. Badurina, Lada (2008). Izmecu redaka: Studije o tekstu i diskursu. Zagreb - Rijeka: Hrvatska sveučilišna naklada, Izdavački centar Rijeka.

4. Bint Šati, Aiša (1990). Et-Tefsiru el-bejani lil-Kur'ani el-kerim (I tom). Kairo: Darul-Mearif. Blakemore, Diane (1992) Understanding utterances: an introduction to pragmatics. Oxford: Basil. Blackwell.

5. Brinton, Laurel J. (1996). Pragmatic markers in English: Grammaticalizationand discourse functions. Berlin: Mouton de Gruyter.

6. Duranti, Alessandro i Goodwin, Charles (1992). Rethinking Context: Language as an Interactive Phenomenon. Cambridge: Cambridge University Press. 
7. Džanko, Minka (2010). Modalne partikule eben, halt i wohlu njemačkom i njihovi prijevodni ekvivalenti u bosanskom/hrvatskom/srpskom jeziku. Sarajevo: Bosansko filološko društvo.

8. Ebul-Azm, Abdulganij (2001). Mudžemu-ganij (IV tom). Bejrut: Darulmektebe el-ilmijje. El-Asfehani, Ragib (1997). Mufredatu alfayilKur'an. Džedda: Darul-Bešir.

9. El-Eškar, Muhammed Sulejman (1995). Mudžemu ulumil-lugati elarebije. Bejrut: Muesesetu er-Risale.

10. Es-Sujuti, Dželaluddin (2004). El-Itkan fi ulumil-Kur'an (I tom). Medina: Mudžema el-melik Fehd.

11. Ez-Zemahšeri, Ebu-Kasim Mahmud (2001). El-Keššafu an hakaiki ettenzili ve ujunil-ekavili fi vudžuhi et-te'vil (IV tom), Bejrut: Daru ihja' et-turasil-arabi.

12. Harden, Theo (1983). An analysis of the semantic field of the German particles "überhaupt" and "eigentlich". Tübinger Beiträge zur Linguistik, volume 2007. Gunter Narr Verlag.

13. Ibn Ašur, Muhammed Tahir (1984). Et-Tahriru vet-tenvir (XXX tom). Tunis: Ed-Daru Et-tunisijje lin-nešr.

14. Karlić, Virna; Tušek, Jelena (2013). Čestice u nastavi južnoslavenskih jezika. Opera Slavica, XXIII, 2013, 4. str. 208-214.

15. Kodrić, Snježana (2002). Riječi na granici punoznačnosti. Zagreb: Hrvatska sveučilišna naklada.

16. Levi, Jirži (1982). Umjetnost prevođenja (preveo Bogdan L. Dabić). Sarajevo: Svjetlost.

17. Muftić, Teufik (1997). Rječnik arapskog jezika. Sarajevo: El-Kalem.

18. Nigoević, Magdalena (2010). Diskursne oznake u hrvatskom i talijanskom jeziku (Kontrastivna analiza). Doktorska disertacija. Sveučilište u Zadru.

19. Nigoević, Magdalena (2011)a. Pristupi diskursnim oznakama $u$ jezikoslovnoj tradiciji engleskoga govornog područja. Folia linguistica et litteraria: Časopis za nauku o jeziku i književnosti (3/4). Nikšić: Institut za jezik i književnost, Filozofski fakultet. str. 57-76. 
20. Nigoević, Magdalena (2011)b. Neka načela odredivanja diskursnih oznaka. Rasprave Instituta za hrvatski jezik i jezikoslovlje 37/1, Zagreb. str. 121-145.

21. Pranjković, Ivo (2009). Nepromjenjive riječi i gramatika u Zborniku radova „Njegoševi dani (ur. Tatjana Bečanović). Cetinje: Univerzitet Crne Gore, Filozofski fakultet Nikšić. str. 329-335.

22. Prčić, Tvrtko (2008). Semantika i pragmatika riječi (Drugo, dopunjeno izdanje). Novi Sad: Zmaj.

23. Sperber, Dan i Wilson, Deirdre (1995). Relevance: Cummunication and Cognition. Oxford: Blackwell.

24. Tekavčić, Pavao (1989). Prema kontrastivnoj pragmatici tzv. „čestica“ u hrvatskom ili srpskom i talijanskom jeziku u Rad JAZU, knj. 427, str. 127-194.

25. Unejs, Ibrahim; Es-Savalihi, Atijje; Halefullah Ahmed, Muhammed; Muntesar, Abdulhalim (1972). El-Mudžemu el-vesit. Kairo: Mektebetu eš-šuruk ed-devlijje.

26. Vidić, Jasna (2013) Prevod stručnog i naučnog teksta u svetlu interpretativne teorije prevođenja. Komunikacija i kultura online, IV/4. str. 109-123.

\section{Izvori}

1. Karabeg, Ali Riza (1991). Kur’an - prijevod Hadži Ali Rize Karabega (drugo izdanje). Zagreb: August Cesarec.

2. Pandža, Muhamed i Čaušević, Džemaludin (1969). Kur’an Časni prijevod i tumač (drugo izdanje). Zagreb: Stvarnost.

3. Korkut, Besim (1977). Kur'an s prevodom. Sarajevo: Orijentalni institut.

4. Mlivo, Mustafa (2004). Kur'an. Prevod sa arapskog na bosanski (treće izdanje). Bugojno: Medžlis Islamske zajednice.

5. Karić, Enes (1995). Kur'an sa prijevodom na bosanski jezik. Sarajevo: Bosanska knjiga.

6. Duraković, Esad (2004). Kur'an s prijevodom na bosanski jezik. Sarajevo: Svjetlost.

7. Mehanović, Muhamed (2013). Plemeniti Kur'an. Približno značenje prijevoda na bosanskom jeziku. Arizona: Lies Stiftung. 
Mr. Belkisa Dolić ${ }^{34}$, Mr. Nedim Haračić

\section{ARABIC MODAL PARTICLES AND ADEQUACY OF THEIR TRANSLATION EQUIVALENTS IN THE BOSNIAN LANGUAGE: SURA ET-TEKASUR}

\section{Abstract}

The introductory part of the paper provides a brief overview of the issues that are connected to a translation craft and with modal words as a category whose struggle for linguistic identity has been going on for a long time, and the final outcome only recently began to emerge on the horizon of the pragmatic, linguistic and discourse studies. The main goal of this paper is to define and describe the communicative-pragmatic function of Arab modal words hatta, kella, sevfe, sume, lev, le and $n$ and their actualization in SuralChapter EtTekasur, and then assessing the adequacy of existing translation equivalents for the same words in the Bosnian language as well as finding new ones, more competent in the case of such proceedings impose as required. As our corpus will serve Sura/Chapter Et-Tekasur in the original Quran (in Arabic) and its seven translations in Bosnian language: Ali Riza Karabeg (1991), Džemaludin Čaušvić and Muhamed Pandža (1969), Besim Korkut (1977), Mustafa Mlivo (2004), Enes Karić (1995), Esad Duraković (2004) and Muhamed Mehanović (2013).

Key words: modal words, particles, discourse markers, multifunctional, equivalents.

\footnotetext{
${ }^{34}$ Pedagoški fakultet Univerziteta u Bihaću.
} 


\section{م. بلقيسة دوليتش •`وم. نديم هاراتشيتش}

أدوات الشرط في اللغة العربية ومناسبة معادلاتها المترجمة في اللغة البوسنوية سورة التكاثر نموذجاً

\section{الخلاصةة}

يقدم مدخل البحث عرضاً قصيراً عن مشاكل متعلقة بحرفة الترجمة وأدوات الشرط باعتبارها فئة يطول كفاحها للحصول على الهوية اللغوية وحصيلة ذلك بدأت تظهر في أفق الدراسات الواقعية (اللغوية) والتوجهية. الهدف الأسـاسي للبحث هو هو تأكيد

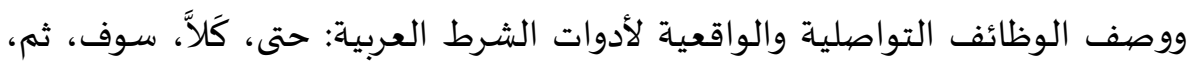
لو، لَ، نون التأكيد، وواقعيتها في سورة التكاثر وبعد ذلك تقدير مناسبة معادلاتها

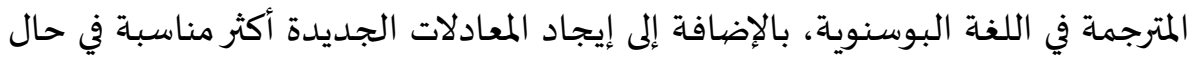

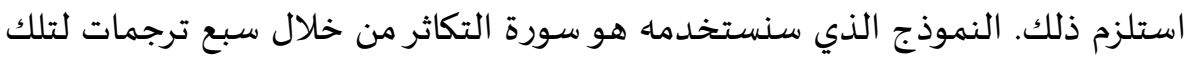
السورة إلى اللغة البوسنوية، وهي: ترجمة علي رضا قارابيك (1991)، جمال الندال الدين

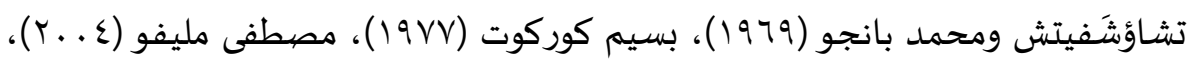

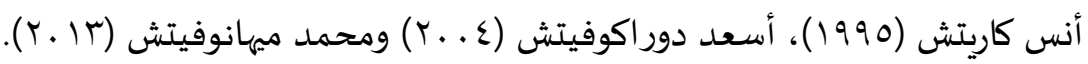

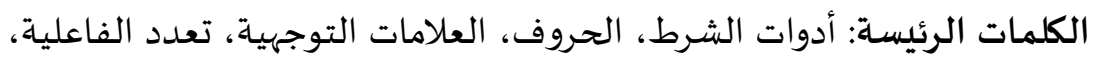

